Mini review

\title{
Progress in Nanomaterials-based Electrochemical Biosensors for Beta-amyloid Peptides as the Biomarkers of Alzheimer's Disease
}

\author{
Yun-Xiao Feng* and Chang-Dong Chen ${ }^{*}$ \\ College of Chemistry and Chemical Engineering, Pingdingshan University, Pingdingshan, Henan \\ 467000, People's Republic of China \\ "E-mail: 2743@pdsu.edu.cn (Y.F.); qgfenghxx@163.com (C.C.)
}

Received: 23 December 2021 / Accepted: 17 January 2022 / Published: 2 February 2022

\begin{abstract}
Alzheimer's disease (AD) have affected the older population worldwide through the rapid decline in cognitive impairment. Mounting evidence suggest that beta-amyloid peptide $(\mathrm{A} \beta)$ and its derivates are closely related to the emergence and growth of $\mathrm{AD}$. Thus, the specific and sensitive detection of $\mathrm{A} \beta$ species have an important role in the early diagnosis of AD. Electrochemical method is a promising candidate for bioassays. The current review mainly focuses on the development of nanomaterials-based electrochemical biosensors for $A \beta$ species in the past decades. We cover the comprehensive utilization of nanomaterials in biosensor construction as the electrode substrate and signal reporters.
\end{abstract}

Keywords: Alzheimer's disease; beta-amyloid peptide; electrochemical biosensor; nanomaterials

\section{FULL TEXT}

(C) 2022 The Authors. Published by ESG (www.electrochemsci.org). This article is an open access article distributed under the terms and conditions of the Creative Commons Attribution license (http://creativecommons.org/licenses/by/4.0/). 